\title{
An Exploration of Contingent Faculty Experiences at a Private, Liberal Arts College
}

\author{
Dr. Erin Vicente ${ }^{a^{*}}$ \\ a Communication Department, Lasell College. \\ ${ }^{*}$ Corresponding author's email address: evicente@lasell.edu
}

\section{A R T I C L E I N F O}

Received: 01-03-2017

Accepted: 28-03-2017

Available online: 29-03-2017

Keywords:

Contingent faculty;

External factors;

Internal factors;

Interpersonal relationships;

Institutional support systems;

Qualitative study;

Voice.

JEL Classification:

E58; G13.

\begin{abstract}
A B S T R A C T
Both internal and external factors have incited higher education institutions to reevaluate and restructure antiquated policies and practices that influence contingent faculty support systems and contingent faculty interpersonal relationships with their institutional community members. Current literature and research has yet to truly explore what contingent faculty are experiencing (Meixner et al., 2010). In order to equip institutions with the necessary understanding of contingent faculty, and practices and policies that provide institutional support systems for their contingent faculty, more qualitative studies that explore the experiences of an individual institution's contingent faculty, are needed. This qualitative study explores contingent faculty experiences at a single institution through their own voice. Focus on an interpretative phenomenological approach allows for rich, descriptive storytelling that communicates the uniqueness and distinctiveness of the contingent faculty's experiences, and their perceptions of how they identify and connect with their institutional support systems and institutional members. Such specificity also highlights the institution's cultural values and norms. While some shared experiences were similar among contingent faculty, there were also experiences unique to the individual. Exploration of contingent faculty voice is imperative in driving institutional platforms that aid in creating positive institutional support systems for contingent faculty.
\end{abstract}

(C) 2017 The Authors. This is an open access article under the terms of the Creative Commons Attribution License 4.0, which allows use, distribution and reproduction in any medium, provided the original work is properly cited.

DOI: http://dx.doi.org/10.18533/rss.v2i3.91

ISSN 2378-8569(Print), ISSN 2378-8550(Online)

\section{Introduction}

As colleges continue to strive to remain financially sound by growing student populations and campuses, it seems their budgets consistently dwindle, which includes cutbacks to full-time faculty hiring (Maldonado \& Riman, 2009). More than ever, colleges are relying on contingent faculty to excel not only in teaching, but other institutional goals (Maldonado \& Riman, 2009). Contingent work is defined by Labor Economists as "any job in which an individual does not have an explicit or implicit contract for long-term employment or in which the minimum hours worked can vary in a nonsystematic manner" (Umbach, 2007, p. 93). According to the U.S. Department of Education's Digest of Educational Statistics, higher education institutions now employ over half a million contingent faculty nationwide (Maldonado \& Riman, 2009). Contingent faculty includes both full- and parttime positions that are off the tenure-track and represent three out of four new faculty appointments (Kezar \& Sam, 2013). There is little doubt that with college enrollments increasing, employment of contingent faculty will continue to increase (Maldonado \& Riman, 2009). Both internal and external factors have incited appeals for reform in higher education and its contingent faculty employment policies and practices (Baldwin \& Chronister, 2001). Department and institutional work environments of contingent faculty tend to be negative because of 
outdated policies and practices that do not support contingent faculty (Kezar \& Sam, 2013).

Contingent faculty offer institutions flexibility by increasing or decreasing the number of courses being offered based on student enrollment numbers (Meixner, Kruck, \& Madden, 2010). Further, contingent faculty hiring allows institutions tractability in hiring at lower costs (Waltman, Bergom, Hollenshead, Miller, \& August, 2012). As such, contingent faculty salaries are much lower than full-time faculty (Kimmitt, 2009). Even so, many contingent faculty make the choice to teach and their vulnerability to an institution's exploitation is evident (Modarelli, 2006). Contingent faculty cannot continue to be a means to service an end (Modarelli, 2006). Demands to teach a wider range of students with diverse needs, as well as teachers being held accountable for learning outcomes, puts tremendous pressure on contingent faculty to perform to high standards with little support (Waltman et al., 2012). While some disciplines have larger percentages of contingent faculty, many contingent faculty consistently experience the same common problems. They lack the compensation, benefits, inclusion in departmental social events, curriculum decision-making, professional development, respect, well-equipped offices and supplies, and overall open lines of communication that full-time faculty members enjoy (Fagan-Wilen, Springer, Ambrosino, \& White, 2006). However, although contingent faculty can be a valuable resource in helping an institution achieve its mission, such experiences have led many contingent faculty to feel a sense of low job security and for their teaching standards to be compromised (Wallin, 2004). Research suggests contingent faculty who feel undervalued will not bring the same quality of teaching compared to those that feel valued and a part of the department team (Milliken \& Dustin, 2008). Umbach (2007) states most contingent faculty spend less time with students and use less engaging teaching methods than tenure-track faculty. Furthermore, such minimal job security for contingent faculty can lead to relying heavily on positive student-teacher evaluations and possible grade inflation (Fagan-Wilen et al., 2006). As such, contingent faculty have just as much opportunity as full-time faculty to impact and influence an institution and its members either negatively or positively. With the increasing hiring of contingent faculty, institutions' understanding of contingent faculty experiences and how contingent faculty perceive their institutional support systems, plays an integral role in how institutions will reform their practices and policies for contingent faculty.

Current literature and research has yet to truly explore what contingent faculty are experiencing (Meixner et al., 2010). In order to equip institutions with the necessary understanding of contingent faculty, and practices and policies that provide institutional support systems for their contingent faculty, more qualitative studies that explore the experiences of an individual institution's contingent faculty, are needed. One-on-one interviews with contingent faculty at their specific place of employment will strengthen current research by giving livedperspectives from various contingent faculty on their day-to-day experiences at their institutions. By describing, explaining, and finding common themes in the sample participants' language, the research will offer a concrete picture of contingent faculty's experiences relevant to their specific institutions. Such research will aid in advancing the specific institution's awareness of how to include, manage, evaluate, and recognize their contingent faculty (Waltman et al., 2012). In doing so, contingent faculty may be given opportunities to feel more valued through their institutional support systems which include their interpersonal relationships with members of their institutional community.

In recent years, the broader social, economic, and political landscapes in which colleges and universities operate has changed (Baldwin \& Chronister, 2001). Both external and internal influences such as lack of government support, new technologies, competition, rising costs, and changing characteristics of students are some of the few reasons for the need to re-evaluate the employment practices and policies at higher education institutions, such as the use of contingent faculty to meet institutional missions (Baldwin \& Chronister, 2001). Significant transformations in the American workplace, because of market changes, have led many types of organizations to restructure their current employee-employer relationships through new policies and practices (Baldwin \& Chronister, 2001). Therefore, many higher education constituents feel that colleges and universities should make the same types of transformations in restructuring antiquated contingent faculty-institutional relationships and the policies and practices that influence such relationships (Baldwin \& Chronister, 2001).

David W. Leslie and Judith M. Gappa, are two of the pioneers and prominent researchers on contingent faculty working conditions and job satisfaction. The social and demographic environments have changed little since Leslie and Gappa's beginning research of part-time faculty in 1982 (Merriam, 2010). Much of their research developed in the 1990's and 2000's, and continues today. However, most of their research has focused on contingent faculty at community colleges through both qualitative and quantitative research, which has not yet gotten to the core of faculty perception through their own description (Leslie \& Gappa, 2002; Meixner, 2010). While Leslie and Gappa note the discrepancies that exist between contingent faculty and full-time faculty, their research hasn't yet fully developed contingent faculty's voice with regard to their own experiences at a small, four-year, private liberal arts institution (Gappa, 2008). 
Although research on contingent faculty working conditions and job satisfaction began in the late 1970's and early eighties, today, the research remains vague at dissecting contingent faculty's own perceptions of what they are experiencing at their individual workplace (Umbach, 2007). Much of the research classifies faculty as a generalizable, homogenous group, and most institutions treat all contingent faculty alike (Baldwin \& Wawrzynski, 2012; Gappa, 1993; Umbach, 2007). As such, research suggests institutions often fall short in supporting their contingent faculty by assuming all contingent faculty identify and connect with their institutions in the same way (Arsdale, 1978; Hoyt, 2012). Various institutions act as unique "labor markets" and yet, if stakeholders in higher education could distinguish the differences in experiences and perceptions between contingent faculty at different institutions, much could be learned in order to improve contingent faculty's connection to their specific institution (Conley \& Leslie, 2002). Exploration of contingent faculty experiences at their individual institution will provide stories of rich dialogue that will address issues beyond compensation to interpersonal relationships within the contingent faculty member's place of employment. Therefore, a study that focuses on one specific institution will answer precisely what support systems are in place that encourage or discourage their contingent faculty from making a deep connection with their institution (Arsdale, 1978).

\section{Theoretical framework}

\subsection{Social exchange theory}

Social exchange theory (SET) suggests "that individuals form relationships with those who can provide valued resources. In exchange for these resources individuals will reciprocate by providing resources and support" (Umbach, 2007, p. 93). Further, individuals who feel supported and rewarded will have greater commitment to an organization (Umbach, 2007). As Homans (1982) argued, social exchange will not likely continue unless each party rewards the other. Social exchange happens under two provisions: there is a goal to meet an end through social interaction with other people, and means must be adapted to foster achievement of such ends (Blau, 1964). One can think of these provisions with contingent faculty having the end goal of providing students with a sound learning experience through their teaching, thus the social interaction lying between contingent faculty and their students. Further, contingent faculty may adapt their teaching methods and style, thus their means of teaching, to achieve valuable learning experiences for their diverse student populations. Additionally, the provisions can also be applied more broadly between contingent faculty and their institutions. Institutions have an end goal of hiring contingent faculty to teach a course start to finish through social interactions with many vested parties. Moreover, institutions have a responsibility to adapt their employment policies and practices (means) to aid in contingent faculty support systems that explicitly define contingent faculty job roles, sustain contingent faculty employment, and help contingent faculty provide a valuable education to students.

Social exchange is voluntary for individuals, and as Gouldner (1964) believed, the "starting mechanism" for such exchange was the reciprocity of such rewards so as to continue to receive them (Blau, 1964, p. 92). Reciprocity is ambiguous; it relies on exchanges being dependent on the actions and behaviors of the participants, as well as the cultural values of the members, within an exchange (Cropanzano \& Mitchell, 2005). However, Blau argued (1964) that the "starting mechanism" for exchange is not reciprocity, but in the existential conditions of exchange, it focuses beyond economic exchange (p. 92). Instead, exchange is innate, and the reciprocity of benefits is merely a check-and-balance system to put individual interests aside, and instead reinforce collective group bargaining for group social norms (Blau, 1964). Further, the exchange may not always be known in advance and the nature of the return is often left up to the discretion of the one who makes it (Blau, 1964). These ideas can be applied to contingent faculty at higher education institutions. Contingent faculty voluntarily teach, and so, they give their time, energy and knowledge, in exchange for the resources, both extrinsic, for example pay, and intrinsic, like collegiality, that their institution provides. However, contingent faculty are expected to follow group norms that match their individual institution's culture of how contingent faculty should behave with regard to their job roles. Yet, those contingent faculty that feel they are not supported nor provided adequate resources for their teaching, will most likely be less committed to their institutions and their students. The return on investment for contingent faculty lies in the hands of those with power within their institutional domains such as administration and fulltime faculty, who may govern the types of exchange and the degree of reciprocity given (Blau, 1964).

Social exchange expands beyond economic exchange and looks at feelings such as trust, obligation, and gratitude (Blau, 1964). In contrast to economic commodities, the benefits of social exchange are sometimes unspecified and not able to be quantitatively measured (Blau, 1964). Rules of exchange are governed by the participants with more power in an exchange relationship (Blau, 1964; Cropanzano \& Mitchell, 2005). There is value in both the extrinsic and intrinsic benefits, and the significance of both are rarely determined by one single factor although the interpersonal relationships between exchange partners influences both benefits (Blau, 1964). Social exchange relationships flourish when employers "take care of employees" (Cropanzano \& Mitchell, 2005, p. 882). Therefore, the only way to take care of employees is to understand them. As such, the exploration of contingent faculty 
experiences will rely on Homans' and Blau's work by exploring individual contingent faculty experiences through their own perceptions of what extrinsic and intrinsic support systems exist in being a contingent faculty member at their individual institution. Social exchange theory will help discover whether the exchange for reciprocity between contingent faculty and their institution is equally valued and supported, if contingent faculty and their institution are equally committed to providing a mutually beneficial relationship, and how relationships and power influence exchanges between participants.

\section{Methodology}

The researcher followed an interpretative phenomenological approach (IPA) through a qualitative study that explored experiences of four individual contingent faculty at a small, private liberal arts college. The following research and sub question drove the study:

\subsection{Research question}

- What are the experiences of contingent faculty at a private, liberal arts college?

\subsubsection{Sub question}

- How does contingent faculty at a private, liberal arts college view their institutional support from both the institution and through interpersonal relationships with their institutional community members?

\subsection{Research design}

An IPA approach through a qualitative study allowed participants the opportunity to speak candidly and specifically through subjective reflection, and the researcher, the opportunity to capture the sense-making of the participants' experiences through her writing (Smith, Flowers, \& Larkin, 2009). Further, qualitative research gave contingent faculty the opportunity to identify similar lived-experiences by collectively sharing their "stories" of institutional experiences through their own voice (Creswell, 2013). The role of the researcher allowed the participant to step outside of their everyday experiences and instead, encouraged more profound descriptions of their experiences through their own complex nuances of sense- and meaning-making (Smith, Flowers, \& Larkin, 2009).

The approach incited a theoretical obligation to the participant by connecting people's talk, their thinking, and their emotional state through the understanding of the participant as a cognitive, linguistic, affective, and physical being (Smith \& Osborn, 2007). Further, the approach helped the researcher explore the experiences of individual contingent faculty participants in their own terms while also being able to connect their understandings to mainstream psychology (Smith, Flowers, \& Larkin, 2009). A smaller sample size helped understand the essential qualities of the institutional experiences for each contingent faculty participant through their own inward awareness of conscious storytelling (Smith, Flowers, \& Larkin, 2009). Further, a small study of contingent faculty at one institution forged the detail of the individual which brought us closer to meaningful qualities of the general (Smith, Flowers, \& Larkin, 2009, p. 32). Stories of reflectivity helped us explore deeper into the individual which took us closer to the universal through similar experiences one may not otherwise have known on the surface (Miles \& Huberman, 1994; Smith, Flowers, \& Larkin, 2009).

A interpretative phenomenological approach examines the reflections of significance in the individual contingent faculty's experiences and the essence, as Husserl believes, of how contingent faculty interpret their own endeavors through a lens of subjective perception (Smith, Flowers, \& Larkin, 2009). Further, Husserl, who was critical of science's privileged claims, argued for a series of reductions that aim at getting at the essence of the participants own perceptions versus the distractions of assumptions and preconceptions of the researcher (Smith, Flowers, \& Larkin, 2009). Unlike Husserl, who believed one needed to disengage from the world and activity in order to experience consciousness of something, Heidegger and Merleau-Ponty believed one need to engage and communicate with the world in order for one to contextualize a perspective on a particular area of the world (Smith, Flowers, \& Larkin, 2009). Heidegger doesn't question the existence of world as Husserl, but instead the significance of the world to the individual (Smith, Flowers, \& Larkin, 2009). Similarly, Merleau-Ponty emphasizes both the physical and perceptual relationships of the body with the world in shaping one's wholeness and uniqueness of knowing (Smith, Flowers, \& Larkin, 2009). Further, he argues each individual's experiences are unique to that individual and can never be shared with another (Smith, Flowers, \& Larkin, 2009). Relatedly, Sartre, further develops Heidegger's and Merleau-Ponty's theories of existential phenomenology that one must exist first before meaning-making can happen (Smith, Flowers, \& Larkin, 2009). An IPA approach developed in response to 
a need for research to go beyond philosophical reflection (Dowling, 2007). The approach emphasizes reflexivity and considers a "human science perspective of inter-subjectivity methodologically, as well as philosophy" (Dowling, 2007, p. 137).

As discussed above, all theorists further developed the idea of meaning-making and all of their ideas can be applied to the research being conducted. Both Schleiermacher and Heidegger understand the ability of the researcher's writing in influencing the interpretation of how one comes to understand a participant's experience (Smith, Flowers, \& Larkin, 2009). Like Heidegger, Schleiermacher notes the impossibility of complete bracketing, and something that can only partially be achieved, however, Schleiermacher also notes how the principles and outlooks of one's own linguistic community can manipulate the appearance of participant's language (Smith, Flowers, \& Larkin, 2009, p. 22). Such philosophies take on the social constructivist strand of qualitative research (Smith, Flowers, \& Larkin, 2009).

\section{4. $\quad$ Research findings}

\subsection{Overview}

Contingent faculty participants' current employment, background, motivations for teaching, length of time teaching, courses taught, self-perception of teaching style, and the role they play in a student's learning experience were varied.

All participants teach face-to-face in the undergraduate program, while two teach in both the undergraduate and graduate program through online, hybrid, and face-to-face courses. Three out of four participants were interviewed one time, up to 120-minutes, while one participant was interviewed twice for a total of 137-minutes for additional questions and further descriptive clarification to responses. Interviews were conducted at all different locations throughout the greater Boston area at the participant's location of choice. All interviews started with the same protocol, however, interview questions were used flexibly, and the questions and order of questions were based on participant responses.

While the contingent faculty interviewed have had unique and separate professional and social experiences both within and outside of contingent teaching, nine overarching themes emerged through the descriptive, lengthy discussions: defining contingent faculty by contingent faculty, contingent faculty perceptions of differences between full-time and contingent faculty, contingent faculty's assessment of the institutional community's lens, institutional investment in contingent faculty, institutional culture surrounding contingent faculty relationships and belongingness, evaluation/feedback, reliability of employment, contingent faculty definition of job satisfaction and perception of job reward, and predicating the future and institutional recommendations by contingent faculty. Interestingly, three out of the four contingent faculty had similar experiences and perceptions of institutional support, when associated as a whole group.

\subsection{Implications}

\subsubsection{Overview}

The purpose of this research was to deeply explore contingent faculty experiences at a single institution, and their perceptions of institutional support from both the institution and through interpersonal relationships with their institutional community members. By focusing on a single institution, experiences are not simplified. Instead, experiences are focused and comprehensive on the particular institutional support systems and relationships most important to contingent faculty at their individual institution. Exploration of an individual, private institution's contingent faculty will provide the chance to better understand contingent faculty experiences, and how contingent faculty perceive their role and support systems within their own institutional community (Smith, 2007). Such research provides an opportunity for an institution to build strong relationships with their contingent faculty which may also offer the chance to provide students with a more valuable education (Modarelli, 2006). Much of the research classifies faculty as a generalizable, homogenous group, and most institutions treat all contingent faculty alike (Baldwin \& Wawrzynski, 2012; Gappa, 1993; Umbach, 2007). As such, research suggests institutions often fall short in supporting their contingent faculty by assuming all contingent faculty identify and connect with their institutions in the same way (Arsdale, 1978; Hoyt, 2012). Literature suggests that department and institutional work environments of contingent faculty tend to be negative because of outdated policies and practices that do not support contingent faculty (Kezar \& Sam, 2013).

The participants were able to provide an increased understanding of their experiences and institutional support specific to their institution's unique cultural fabric. Their willingness to give rich, detailed descriptions through 
stories and examples of what they have experienced showcases their openness and comfort in sharing their voice. It also underlines their need to feel valued by their institutional communities. Their discussions call for institutions to rethink, reorganize, and restructure antiquated contingent faculty-institutional relationships, policies, and practices that remain unexplored, undisputed, and unchanged (Baldwin \& Chronister, 2001; Feldman \& Turnley, 2004; Kezar \& Sam, 2013). Further, understanding contingent faculty experiences could lead to the possibility to further explore what is needed for contingent faculty to feel valued through institutional support (Meixner et al., 2010; Smith, Flowers, \& Larkin, 2009).

Much of the research on contingent faculty contradicts contingent faculty experiences (Meixner et al., 2010). Such contradiction advances demand for more robust studies that limit such discrepancies in areas such as contingent faculty institutional commitment, satisfaction, and teacher preparation (Meixner et al., 2010). An interpretative phenomenological approach allowed for contingent faculty to express their feelings and perceptions fully by allowing room for their own stories to emerge through flexible interview questions. The contingent faculty interviewed expressed a need for better economic equity, but also stronger interpersonal relationships with their institutional community members which influenced how much they feel supported and rewarded (Blau, 1964). Relationships flourish when employers "take care of employees" (Cropanzano \& Mitchell, 2005, p. 882; Umbach, 2007). The contingent faculty disclosed feelings of embracement, obligation, and gratitude as benefits of feeling rewarded. Individuals who feel supported will have greater commitment to an organization (Cropanzano \& Mitchell, 2005, p. 882; Umbach, 2007). As admitted by the contingent faculty, they each questioned their own willingness to be fully committed to their institution because they do not feel the return on investment. Areas that contingent faculty felt a lack of institutional investment and commitment were professional development, pay, workspace, evaluation/feedback from their supervisors, interpersonal relationships with institutional community members, and reliability of employment. Instead, those areas have merely served as a check-and-balance system for the institution to follow group norms so their contingent faculty will behave in accordance with their assigned roles and what they are expected to do (Blau, 1964).

\section{Discussion of research findings}

\subsection{Research question 1}

\section{What are the experiences of contingent faculty at a private, liberal arts college?}

Contingent faculty confirmed that there are times that they feel disenfranchised within their institution. However, all contingent faculty participants expressed that they have partial responsibility for how much they are invested in by their institution and how strong their interpersonal relationships are with institutional community members. All contingent faculty interviewed confirmed research that they have either a lower voice or not the same kind of voice as full-time faculty (Baldwin \& Chronister, 2001). However, they partially accept some responsibility in choosing such voice. The flexibility of the job doesn't require them to be invested beyond showing up to teach their classes. They admitted they like the flexibility in being able to come and go as they please and not having to communicate with either their supervisors or other members of the faculty if they don't wish to. However, each contingent faculty member grappled with the idea of having freedom and flexibility versus being more invested in their institution and with their institutional community members. They saw their own investment as a reflection of how much the institution may be inclined to support them. Such reflection indicates the potential of both parties, the contingent faculty member and the institution, to play on each other as a means of growing stronger support systems through each other's investment. While contingent faculty appreciate the avenue of being able to do what they want, they question whether that is truly an advantageous and ethical feature of their job. In fact, they question whether such a hands-off approach manifests their separation from other fulltime faculty by not being as invested. The contingent faculty note that it may be more beneficial if they had relationships with other faculty so they could take advantage of opportunities such as brainstorming about effective teaching practices.

\subsubsection{Commitment}

Higher education institutions that include, reward, and value contingent faculty contribution are more likely to have contingent faculty who will increasingly develop strong emotional ties to the organization (Merriam, 2010). Further, contingent faculty will be more likely to take on tasks that are relative to institutional goals rather than individual interests (Merriam, 2010). If contingent faculty identify with their institution, their sense of belonging increases (Merriam, 2010). When contingent faculty feel like they belong, they are able to identify with their institution more (Merriam, 2010). It was evident that all of the contingent faculty interviewed felt there was some surface-level outreach by the institution to include them in professional development or other institutional initiatives. However, participants noted that they often felt out-of-place when attending such opportunities 
because often other contingent faculty don't attend, and/or full-time faculty and other institutional community members don't make a concerted effort to engage them. As noted by one contingent faculty member, she has been left in a corner by herself during an event. Comparatively, two contingent faculty did not feel a desire to have to commit to the institution beyond their teaching. The two contingent faculty specifically called to attention their lack of institutional investment because they did not feel the monetary reward to participate in extracurricular initiatives was worth it. They questioned investing their time and energy in doing anything beyond teaching because they either felt their job description doesn't warrant it, and/or the institution doesn't take any steps to value the contingent faculty. On the other hand, the other two contingent faculty did not feel as committed to attending professional development initiatives for such little compensation, but they were committed in meeting with students outside of class if need be.

\subsubsection{Compensation \& job reliability}

The contingent faculty members interviewed were dissatisfied with compensation, but were satisfied with other aspects of their job. All contingent faculty noted that they do not feel the compensations represents what they do in terms of their work. Three contingent faculty admitted to working more than the average 40-hour work week, and felt they deserved greater compensation. Further, three contingent faculty criticized job security. Interestingly, one of those three contingent faculty members, who works full-time outside of teaching, noted the same insecurities said by two other contingent faculty members in being rehired. Although all three contingent faculty are at different career stages, they believed that an email blast was an unfair and insufficient way to guarantee whether they are rehired or not. They described that if they missed the email then the opportunity for them to teach is lost because it works on a first-come, first-serve basis. Such methods prove daunting in determining the predictability of being rehired at their institution. However, all four contingent faculty members were satisfied with the nature of their work in capacities such as scheduling flexibility, job autonomy, and challenge (Feldman \& Turnley, 2001; Waltman et. al, 2012). All of the contingent faculty made a case for what they do because of their passion and love of teaching students. The opportunity and challenge in sharing knowledge and ideas for learning and advancement through opening students' and their own minds is inspiring to the contingent faculty. Despite studies that have revealed a lack of academic support and recognition at universities, all of the contingent faculty felt that the challenge of teaching and learning new material themselves is thrilling (Hoyt et. al, 2008). As such, all considered the low compensation and lack of job reliability as manageable because of other positives such as a love of teaching (Hoyt et. al, 2008).

\subsubsection{Institutional support}

Professional development is defined as "those processes and activities designed to enhance the professional knowledge, skills, and attitudes of educators so that they might, in turn, improve the learning of students..." (Wallin, 2004, p. 383). Contingent faculty confirmed other research that their needs do not differ greatly in areas of professional development when compared to full-time faculty (Wallin, 2004). Similar to other research, the contingent faculty interviewed felt their most desired resource is an increase in pay (Pearch \& Martuz, 2005). However, like other research suggests, the contingent faculty interviewed proposed mentoring, orientation programs, and contingent faculty recognition as ways to build and foster contingent faculty communities that are important to valuable institutional practices of teaching, learning, and productivity (Feldman \& Turnley, 2001; Morton, 2012). They specifically called for systems that would rework current socialization, compensation, inclusion in faculty governance, professional development, information sharing, and administrative and technical support processes (Fagen-Wilen et al., 2006; Kezar \& Sam, 2013). Focus on such matters could help influence improved practices for contingent faculty which could help overall morale (Fagen-Wilen et al., 2006; Kezar \& Sam, 2013).

\subsubsection{Contingent faculty impact on the institution}

Thus far, literature that has examined the teaching practices of contingent faculty has been difficult to interpret because it depicts a complex and contradictory picture of contingent faculty teaching effectiveness compared to full-time faculty teaching effectiveness (Baldwin \& Wawrzynski, 2011). Instructional quality variables such as active learning, preparing well-rounded citizens, class preparation, and diversity experiences have shown that part-time faculty place less of an emphasis on those four variables compared to full-time faculty (Umbach, 2007). Yet, in this study, all of the contingent faculty interviewed gave rich description of their teaching style and practices. They believed that they do just as good, if not a better job than full-time faculty in teaching. All argued that they often spent countless hours learning and creating new material and grading. Further, two contingent faculty detailed how they go out of their way to meet students outside of class that need extra help, mentoring, and any other types of advice or direction. Although research has indicated that full-time faculty may be more committed to teaching, the contingent faculty interviewed contradicted such research as they considered their 
main focus and strongest attribute as their ability to prepare and teach well. For example, they highlighted their implementation of interactive and diverse learning environments that foster settings to prepare and promote well-rounded citizens (Umbach, 2007).

Further, some research suggests that contingent faculty rely heavily on student evaluations (Kirk \& Spector, 2009). Baldwin and Chronister (2001) found that many non-tenure track faculty had concerns in the student evaluation criteria being used and the placement of too much power in the students' hands. They found that many contingent faculty craved to be evaluated in the same manner as full-time faculty (Baldwin \& Chronister, 2001). Three of the contingent faculty interviewed confirmed such skepticism regarding the heavy emphasis on student evaluations which drive their teaching effectiveness. They voiced their concerns at length regarding a need for supervisor evaluation and feedback similar to that of full-time faculty. Such feedback would make them feel more valued, give them a sense of belongingness, and provide constructive feedback to apply to their future course preparation.

\subsection{Research question 2}

How does contingent faculty at a private liberal arts college perceive their institutional support from both the institution and through interpersonal relationships with their institutional community members?

\subsubsection{Institutionalization}

Institutionalization refers to the policies and practices that are part of underlying assumptions or norms that become engrained in the culture of an institution (Kezar \& Sam, 2013). Faculty members determine the quality of an institution, and therefore, administrators and faculty members must make a commitment to work together in an environment of respect and equity (Gappa, Austin, \& Trice, 2005). All of the contingent faculty interviewed acknowledged the status quo of the job which is merely showing up and teaching without having any other responsibilities. They explicitly stated that more support and stronger relationships with other community members could challenge such status quo that creates divisions among faculty (Kezar \& Sam, 2013). The contingent faculty's stories of lack of acknowledgment and relationships highlight the pervasive status differentials among different faculty at the institution (Gappa, 2002). Contingent faculty emphasized the power of their own voice to digress beyond their own job satisfaction and instead, into processes of exchange, which reject underlying norms, values and outdated perceptions at the institution (Blau, 1964; Gappa, Austin, \& Trice, 2005; Kezar \& Sam, 2013). Instead, their processes of exchange revisit past and present relationships between faculty members and their institutional community members (Blau, 1964; Gappa, Austin, \& Trice, 2005; Kezar \& Sam, 2013. Such processes of exchange were magnified by contingent faculty's stories and examples of the dynamic social interactions played out by their individual experiences (Blau, 1960). Unlike other research that paints a confusing picture of contingent faculty experiences and relationships, individual exploration of their own relationships attributed the particularity of what each individual contingent faculty member has experienced and with whom (Wagoner, 2007). Their individuality allowed for specificity through their own storytelling.

\subsubsection{Implications}

\subsubsection{Implications for the institution}

Few studies have covered the cultural fabric-the values, norms, and underlying assumptions that contingent faculty experience at their individual institution through their own voice (Kezar \& Sam, 2013). Contingent faculty hiring is on the rise making-up $42.7 \%$ of all faculty at private institutions (Liu \& Zhang, 2007). Higher education institutions need to restructure antiquated contingent faculty-institutional relationships and the policies and practices that influence such relationships (Baldwin \& Chronister, 2001). A qualitative study of what contingent faculty are experiencing at a single institution specifically illustrates the distinctions of the institution. It also details how to advance an institution's ability to raise awareness of how to include, manage, evaluate and recognize their own contingent faculty (Waltman, 2012). Experiences are focused and comprehensive on the particular institutional support systems and relationships most important to contingent faculty at their institution. Detailed accounts at a single institution exposes any superficiality and inaccurate efforts in a "onesize-fits-all" model of research that covers multiple institutions (Baldwin \& Chronister, 2001; Gappa, Austin, \& Trice, 2005, p. 36).

If the current institution has a better understanding of their contingent faculty, they would be able to provide resources that help contingent faculty feel more supported and rewarded (Umbach, 2007). If the institution knows more about their contingent faculty, then they would not waste time, energy, or money on programs and resources that may be useless in aiding their contingent faculty. As such, contingent faculty may have a greater commitment 
to their institutional community (Umbach, 2007). If the institution can adapt their employment practices and policies, and explicitly define contingent faculty job roles, then they can better serve that population. As the institution has evolved, they have not evolved their understanding of contingent faculty experiences. They cannot continue to classify them as a separate group when they have such a large stake in the success of the institution. As an over 100-year old higher education institution, there is a demand to not only change structurally, but internally.

Further, full-time faculty may be able to develop relationships with the contingent faculty's external communities which could also help the institution with funding for future growth (Gappa, Austin, \& Trice, 2005).

\subsubsection{Implications for chairpersons}

All contingent faculty discussed the importance of requiring supervisor evaluation. If chairs were required to evaluate their contingent faculty it could give them insight to the value the contingent faculty member is bringing to the student. It could also help develop and foster relationships with their contingent faculty by understanding their contingent faculty's strengths and how those may be best suited for teaching certain courses, and utilized in department initiatives. Further, it would help strengthen contingent faculty's morale because contingent faculty would feel as valued as full-time faculty. Currently, the contingent faculty solely rely on student evaluations as a measure for their effectiveness in the classroom. This poses as a problem because student evaluations may not be as accurate a measure of teaching effectiveness because students lack the maturity and pedagogical knowledge to evaluate contingent faculty. Further, one contingent faculty member questioned her own integrity and whether she is not as rigorous in the classroom, and in fact, grades leniently because she is aware of the relationship between student satisfaction and her job. If contingent faculty could be guaranteed supervisor evaluation they would not need to rely on the word of the student or implicate their own teaching practices. Instead, they would feel more valued by having the support and feedback from their supervisor as to whether they are doing a good job or not. As the college moves toward assessing more student work and department performance, it is imperative that contingent faculty are given feedback by academic professionals such as their Chair. Contingent faculty are responsible for student outcomes, as well as teaching effectiveness, but if they are not observed then both they and the students are being served injustice.

\subsubsection{Implications for students}

The institution's ability to understand their contingent faculty provides a more valuable student education because the institution can provide the appropriate resources and support systems that would help their contingent faculty to improve and carry-out the most effective teaching practices. (Modarelli, 2006). For example, improving opportunities for professional development can improve instructional quality (Zeigler \& Reiff, 2006). The institution in this study relies heavily on their contingent faculty.

\subsubsection{Implications for full-time faculty}

As referenced by the contingent faculty participants, they feel there is opportunity for full-time faculty to learn just as much from the contingent faculty's experiences and knowledge as they could learn from the full-time faculty's pedagogical experiences. Contingent faculty members felt that their experiences and relevancy can often be as strong if not stronger than full-time faculty because full-time faculty may not have been out in the industry for some time. Therefore, if full-time faculty look to build and continuously strengthen their relationships with contingent faculty, they too could gain new insight into growing practices in the field which they could then implement in their teaching and curriculum. One contingent faculty participant mentioned how important social media is to organizations today and that not all full-time faculty understand how to use such important forms of communication. Contingent faculty have connections to the community and are aware of new technologies, ideas, and practices within their respective fields (Gappa \& Leslie, 1993). If both contingent and full-time faculty found more time for collaboration new knowledge could be shared. Also, currently the institution is carrying out a new core curriculum that would require more multidisciplinary courses taught by two professors in two different disciplines. Such growth in the multidisciplinary area could benefit from contingent faculty knowing other fulltime faculty for these team teaching purposes.

\subsubsection{Implications for contingent faculty}

Contingent faculty who feel valued through institutional support will view themselves as contributors to their institution which creates a sense of belonging within their institutional community (Morton, 2012). Higher education institutions that include, reward, and value contingent faculty contributions are more likely to have contingent faculty who will increasingly develop strong emotional ties to the institution, and, therefore, will be more committed to the institution (Merriam, 2010; Umbach, 2007). Three of the contingent faculty have been 
employed for over 5 years which is not short-lived, and shows their investment to the field of teaching. Also, although one contingent faculty member has only taught for one year, she is invested because she is a former alumna as well. Therefore, each contingent faculty member knows they drive the quality of education (Gappa et al. 2005; Mazurek, 2012). For example, one contingent faculty member even spoke about the institution needing continent faculty to survive. If the institution invests in areas the contingent faculty feel are needed and areas they value, contingent faculty can continue their employment for the long term which could aid in contingent faculty becoming part of and more immersed in the institutional community.

\subsubsection{Implications for future research}

As contingent faculty numbers continue to rise with $42.7 \%$ of faculty at a private institution comprised of contingent faculty, a key implication of this study is the need for additional research on contingent faculty experiences (Liu \& Zhang, 2007; Maldonado \& Riman, 2009). There were similar topics of discussion and feelings such as marginalization and lack of fair compensation among all the contingent faculty interviewed. However, there were some contradictions between the contingent faculty participants' experiences. For example, internal contradictions of contingent faculty among their individual experiences were revealed as the interviews evolved and the discussions grew deeper. The study indicated that while some contingent faculty experience similar situations and feelings, not all contingent faculty can be categorized as a generalizable, homogenous group, and institutions shouldn't classify them in that way (Baldwin \& Wawrzynski, 2012; Gappa, 1993, Umbach, 2007). The contingent faculty presented both internal and external factors that have indicated a need for reform in higher education and its contingent faculty employment practices and policies. Such also includes the building and strengthening of interpersonal relationships among contingent faculty and their colleagues (Baldwin \& Chronister, 2001). Various institutions act as unique "labor markets" and yet, if stakeholders in higher education could distinguish the differences in experiences and perceptions between contingent faculty at different institutions, much more could be learned in order to improve contingent faculty's connection to their specific institution (Conley \& Leslie, 2002).

\section{Limitations and future research}

The study had three limitations: researcher's background, timing of the study, and research design.

\subsection{Researcher's background}

The researcher's background as a former contingent faculty member, and now a full-time faculty member at the same institution as the contingent faculty participants are employed, presents bias. First, because of the researcher's vested interest in the topic and her own experiences as both a contingent and full-time faculty member. Second, phrasing of the interview questions could have presented some bias based on the researcher's first-hand knowledge of the institution's policies and practices toward contingent faculty. Third, despite the researcher following proper IRB protocol the contingent faculty interviewed may have had knowledge of the researcher's background. Consequently, they may have been more inclined to feel obligated to participate in the research, and to share more detail of their experiences than they would have wanted to because of faculty status. The contingent faculty may have felt the researcher had an upper-hand during the interview because of the researcher's position.

\subsection{Timing of the study}

The interviews were conducted during a time when the topic of contingent faculty and perimeters of unionizing are on the forefront of discussion in media forums concerning higher education. Such forums have underlined negative perceptions surrounding contingent faculty employment and how contingent faculty are treated by universities and colleges across the country. Therefore, responses could have been influenced by such negative press and perceptions.

\subsection{Research design}

The study was further limited by research design. It is difficult to define what interpretation is, how the interpretation process works, and how to assess the validity of interpretation within qualitative research (Smith, Flowers, \& Larkin, 2009). There is not a reasonable amount of research on contingent faculty experiences at a private, liberal arts college that may be used to examine common features and variations across samples. Therefore, while this research may prove groundbreaking, it will also be demanding and incapable of making wider claims on the phenomenology of contingent faculty, and misinterpretation could occur (Smith, Flowers, \& Larkin, 2009). 
Further, participants were purposefully selected which allowed the researcher to disproportionally select participants from two disciplines rather than various disciplines. As such, the homogeneity of the sample size could encourage similar expressive discussions (Smith, Flowers, \& Larkin, 2009).

\section{Recommendations for future research}

- The first recommendation for research is to continue to move away from both quantitative and qualitative studies that have focused on job satisfaction levels using Frederick Herzberg's 1960's motivator-hygiene model. Herzberg's motivator-hygiene theory has revealed a need for a modified theory on job satisfaction to be created for non-tenure-track faculty (Hoyt et al., 2008; Waltman, 2012). Both methods proved to be significant in studying contingent faculty job satisfaction, but qualitative research offers a deeper, richer understanding of lived experiences of contingent faculty.

- The study should include more contingent faculty participants from various disciplines across the institution. Such diversity would be useful in determining if the contingent faculty participant experiences are department and/or discipline or institution specific or transferable across many colleges and universities.

- The study should be replicated at other higher education institutions both similar and different in scope and size to the institution studied. A comparison of findings across institutions would help verify if contingent faculty experiences are institution or geographically specific, similar only among institutions that are the same, or transferable across many colleges and universities.

- Very few studies have looked at belonging from the viewpoint of the employer (Merriam, 2010). It would be valuable to study the view point of who contingent faculty are, their job role, and how and where contingent faculty fit-in with those who hold full-time faculty and administrative positions within the institution. Comparing the perceptions of full-time faculty and administrative members with contingent faculty perceptions would indicate where the disparities lie. There needs to be an understanding of both similarities and differences of perception among institutional members and contingent faculty. Such could establish a starting point for organizational change toward contingent faculty employment practices and policies, and contingent faculty relationships with other institutional members.

- More interview time must be given for contingent faculty to further explain their recommendations for institutions to better support their population. It would be valuable to allow contingent faculty the interview time to discuss more comprehensively their plans of action for institutions to enact organizational change. Future research should consider interviewing faculty over longer periods of time, and perhaps even create focus groups of contingent faculty to concentrate on areas such as institutional recommendations.

\section{Conclusion}

The purpose of this study was to understand contingent faculty experiences at a single institution through their own voice. As contingent faculty populations continue to grow it is important for the institution to know what institutional support systems contingent faculty value, and how to strengthen interpersonal relationships of contingent faculty and other institutional community members. If contingent faculty feel valued through institutional support, whether accessibility to resources or interpersonal relationships, their sense of belonging will increase along with their commitment to the institution. In doing so, contingent faculty would further their opportunities in making a positive impact on the institution and its various populations such as students and fulltime faculty.

Although some of the contingent faculty experiences were unique to the individual, there were similar experiences that were echoed by all of the contingent faculty members interviewed. Therefore, similar experiences are transferable across the institution which indicates a call for change in current institutional policies and practices regarding contingent faculty. The findings of the study will help facilitate the institution's awareness, availability, mobility, and transformation of current organizational practices for contingent faculty to innovative programs that speak to the voice of contingent faculty members and what they value in support systems. Further, the study highlights the need for future research to continue to allow contingent faculty's voice to steer institutional platforms that aid in creating positive support systems for contingent faculty. The more invested the institution is in their contingent faculty relies on continually conducting research that articulates the evolving and diverse voice of contingent faculty and the complexities and intricacies within such discourse. 


\section{References}

Arsdale, G.V. (1978). De-professionalizing a part-time teaching faculty: How many, feeling small seeing few, getting less, dream of more. The American Sociologist, 13, 195-201.

Baldwin, R.G. \& Chronister, J.L. (2001). Teaching without tenure: Policies and practices for a era. Baltimore, MD: Johns Hopkins University Press.

Baldwin, R.G. \& Wawrzynski, M.R. (2011). Contingent faculty as teachers: what we know; we need to know. American Behavioral Scientist, 55(11), 1485-1509. https://doi.org/10.1177/0002764211409194

Blau, P.M. (1960). A theory of social integration. American Journal of Sociology, 65(6), 545-556. https://doi.org/10.1086/222785

Blau, P.M. (2009). Exchange and power in social life. New York: Wiley.

Burrell, G., \& Morgan, G. (1979). Sociological paradigms and organizational analysis: Element of the sociology of corporate life. London: Heinemann.

Butin, D.W. (2010). The education dissertation: A guide for practitioner scholars. Thousand Oaks, CA: Sage Publications, Inc.

Castillo, J.X. \& Cano, J. (2004). Factors explaining job satisfaction among faculty. Journal of Agricultural Education, 45(3), 65-74. https://doi.org/10.5032/jae.2004.03065

Cherwin, A. (2008, November 9). US: Obama and higher education: Promises and problems. University World News, 52. Retrieved from http://www.universityworldnews.com/article.php?story

Christensen, C. (2008). The employment of contingent faculty at community colleges. New Directions for Community Colleges, 143, 29-36.

Conley, V.M. \& Leslie, D.W. (2002). Part-time instructional faculty and staff: Who they are, what they do, and what they think. Washington, D.C: U.S. Department of Education.

Creswell, J.W. (2013). Qualitative inquiry \& research design: Choosing among five approaches (3rd ed.). Thousand Oaks, CA: Sage Publication, Inc.

Cropanzano, R. \& Mitchell, M.S. (2005). Social exchange theory. Journal of Management, 31(6), 874-900. https://doi.org/10.1177/0149206305279602

Dedman, D., \& Pearch, W.J. (2004). Perspectives on contingent faculty and other non-tenure faculty. Community College Enterprise, 10(1), 23-33.

Dowling, M. (2007). From Husserl to van Manen: A review of different phenomenological approaches. International Journal of Nursing Studies, 44, 131-142. https://doi.org/10.1016/j.ijnurstu.2005.11.026

Fagan-Wilen, R., Springer, D.W., Ambrosino, B., \& White, B.W. (2006). The support of contingent faculty: An academic imperative. Social Work Education, 25, 39-51. https://doi.org/10.1080/02615470500477870

Feldman, D.C., \& Turnley, W.H. (2001). A field study of contingent faculty: The impact of career stage on reactions to non-tenure jobs. Journal of Career Development, 28, 1-16. https://doi.org/10.1023/A:1011193713662

Feldman, D.C., \& Turnley, W.H. (2004). Contingent employment in academic careers: Relative deprivation among adjunct faculty. Journal of Vocational Behavior, 64, 284-307. https://doi.org/10.1016/j.jvb.2002.11.003

Gappa, J.M. \& Leslie, D.W. (1993). The invisible faculty: Improving the status of part-timers in higher education. San Francisco, CA: Jossey Bass-Inc.

Gappa, J.M. (2000). Managed professionals: Unionized faculty and restructuring academic labor. Journal of Higher Education, 71(6), 751-753. https://doi.org/10.2307/2649164

Gappa, J.M. (2002). Teaching without tenure. Perspectives in Biology and Medicine, 45(3), 449-456. https://doi.org/10.1353/pbm.2002.0045

Gappa, J.M., Austin, A.E., \& Trice, A.G. (2005). Rethinking academic work. Change, 37, 32-39. https://doi.org/10.3200/CHNG.37.6.32-39

Gappa, J.M. (2008). Today's majority: Faculty outside the tenure system. The Magazine of Higher Learning, 40(4), 50-54. https://doi.org/10.3200/CHNG.40.4.50-54

Green, D.W. (2007). Contingent faculty and the continuing quest for quality. New Direction for Community Colleges, 140, 29-39. https://doi.org/10.1002/cc.302

Grigaliunas, B.S. \& Herzberg, F. (1971). Relevancy in the test of motivator-hygiene theory. Journal of Applied Psychology, 55(1), 73-79. https://doi.org/10.1037/h0030633

Halcrow, C., \& Olson, M.R. (2011). Contingent faculty: Valued resource or cheap labor? FOCUS on Colleges, Universities \& Schools, 6(1), 1-8.

Hofmans, J., De Gieter, S., \& Pepermans, R. (2013). Individual differences in the relationship between satisfaction with job rewards and job satisfaction. Journal of Vocational Behavior, 82(1), 1-9. https://doi.org/10.1016/j.jvb.2012.06.007

Homans, G.C. (1958). Social behavior as exchange. American Journal of Sociology, 63(6), 597-606. https://doi.org/10.1086/222355

Homans, G.C. (1982). The present state of sociological theory. The Sociological Quarterly, 23(3), 285-299. https://doi.org/10.1111/j.1533-8525.1982.tb01013.x 
Hoyt, J.E. (2012). Predicting the satisfaction and loyalty of adjunct faculty. The Journal of Continuing Higher Education, 60, 132-142. https://doi.org/10.1080/07377363.2013.722417

Hoyt, J.E., Howell, S.L., Glines, L.J., Johnson, C., Spackman, J.S., Thompson, C., \& Rudd, C. (2008). Assessing contingent faculty job satisfaction in continuing higher education: Implications for the profession. The Journal of Continuing Higher Education, 56, 27-38. https://doi.org/10.1080/07377366.2008.10400139

Kezar, A. \& Sam, C. (2013). Institutionalizing equitable policies and practices for contingent faculty. The Journal of Higher Education, 84(1), 56-87. https://doi.org/10.1353/jhe.2013.0002

Kimmitt, M. (2009). A model of contingent faculty in higher education. Economic Letters, 105, 68-70. https://doi.org/10.1016/j.econlet.2009.05.020

Kirk, F.R., \& Spector, C.A. (2009). A comparison of the achievement of students taught by full- time versus contingent faculty in business courses. Academy of Educational Leadership Journal, 13, 73-81.

Leslie, D.W. \& Gappa, J.M. (2002). Part-time faculty: Competent and committed. New Directions for Community Colleges, 118, 59-67. https://doi.org/10.1002/cc.64

Louziotis, D. (2000). The role of contingent faculty: Bridging the dark side and ivory tower. Review of Business, 21, 47-52.

Liu, X. \& Zhang, L. (2007). What determines employment of part-time faculty in higher education institutions? [Electronic version]. Retrieved [March 25, 2015], from Cornell University, School of Industrial and Labor Relations site http://digitalcommons.ilr.cornell.edu/workingpapers/139/

Maggs-Rapport, F. (2000). Combining methodological approaches in research: Ethnography and interpretive phenomenology. Journal of Advanced Nursing, 31(1), 219-225. https://doi.org/10.1046/j.13652648.2000.01243.x

Maldonado, E. \& Riman, J. (2009). The contingent faculty advocate @ fit: Bringing contingent faculty into the mainstream. Journal of Educational Technology systems, 37, 327-333. https://doi.org/10.2190/ET.37.3.h

Maynard, D.C, \& Joseph, T.A. (2008). Are all contingent faculty underemployed? The influence of faculty statues preference on satisfaction and commitment. Higher education, 55, 149-154. https://doi.org/10.1007/s10734-006-9039-z

Mazurek, R.A. (2012). Academic labor is a class issue: Professional organizations confront the exploitation of contingent faculty. J. Workplace Rights, 16(3-4), 353-366. https://doi.org/10.2190/WR.16.3-4.f

McNabb, J. (2013). Lecture Week 3: Interpretive Phenomenological Analysis (IPA) [Screencast]. Retrieved from Proposal Development Qualitative Blackboard: http://www.screencast.com/t/PH8Mp5Dn

Meixner, C., Kruck, S.E., \& Madden, L.T. (2010). Inclusion of contingent faculty for the benefit of faculty and students. College Teaching, 58, 141-147. https://doi.org/10.1080/87567555.2010.484032

Merriam, C.L. (2010). Adjunct faculty organizational sense of belonging and affective organizational commitment (Doctoral dissertation). Retrieved from ProQuest. (Accession No. 3411382).

Milliken, T.F., \& Jurgens, J.C. (2008). Assessing the needs of human services contingent faculty: Uncovering strategies for retaining quality instructors. Human Services Education, 28, 29-43.

Modarelli, M. (2006). A kantian approach to the dilemma of contingent faculty. Changing English, 13, 241-252. https://doi.org/10.1080/13586840600833671

Morton, D.R. (2012). Adjunct faculty embraced: The institution's responsibility. Christian Educational Journal 9(2), 397-407.

Pearch, W.J., \& Marutz, L. (2005). Retention of contingent faculty in community colleges. Community Enterprise, $11,29-44$.

Saldana, J. (2013). The coding manual for qualitative researchers (2nd ed.). Thousand Oak, CA: Sage Publications, Inc.

Smith, J.A., Flowers, P., Larkin, M. (2009.) Interpretative phenomenological analysis: Theory, methods, and research. London, England: Sage Publications Ltd.

Smith, J.A. \& Osborn, M. (2008). Interpretative phenomenological analysis. In J.A. Smith (Ed.), Qualitative psychology: A practical guide to research methods [E-reader version] (pp. 53-79). Retrieved from http://books.google.com

Thomas, D.R. (2006). A general inductive approach for analyzing qualitative evaluation data. American Journal of Evaluation, 27(2), 237-246. https://doi.org/10.1177/1098214005283748

Tomanek, J.K. (2010). Job satisfaction of community college contingent faculty at Midwestern Community College (Unpublished doctoral dissertation). Iowa State University, Ames, Iowa.

Umbach, P.D. (2008). The effects of part-time faculty appointments on instructional techniques commitment to teaching. Paper presented at the 33rd Annual Conferences of the Association for the Study of Higher Education: Jacksonville, Florida.

Umbach, P.D. (2007). How effective are they? Exploring the impact of contingent faculty on undergraduate education. The Review of Higher Education, 30(2), 91-123. https://doi.org/10.1353/rhe.2006.0080

Wagoner, R.L. (2007). Contingent faculty satisfaction across missions and disciplines. New Directions for Community Colleges, 140, 75-81. https://doi.org/10.1002/cc.307 
Wagoner, R.L., Metcalfe, A.S., \& Olaroe, I. (2005). Fiscal reality and academic quality: Part-time faculty and the challenge to organizational culture at community colleges. Community College Journal of Research and Practice, 29, 25-44. https://doi.org/10.1080/10668920390276948

Wallin, D. (2004). Valuing professional colleagues: Contingent faculty in community and technical colleges. Community College Journal of Research and Practice, 28, 373-391. https://doi.org/10.1080/10668920490424087

Wallin, D. L. (2007). Part-time faculty and professional development: Notes from the field New Directions for Community Colleges, 140, 67-73. https://doi.org/10.1002/cc.306

Waltman, J., Bergom, I., Hollenshead, C., Miller, J., \& August, L. (2012). Factors contributing to job satisfaction and dissatisfaction among non-tenure track faculty. Journal of Higher Education, 83(3), 411-434. https://doi.org/10.1353/jhe.2012.0014

Zeigler, C.A., \& Reiff, M. (2006). Contingent faculty mentoring, a vital responsibility in a changing educational climate: The Lesley University contingent faculty mentoring program. Mentoring \& Tutoring, 14, $247-269$. https://doi.org/10.1080/13611260500493667

\section{Appendix A}

Sample Interview Questions for Contingent Faculty Participants

(Flexible Interview Question Guide based on direction of conversation)

\section{Please state gender, age and what department you teach in.}

1. What degrees have you earned and in what discipline? What is your professional experience?

2. How long have you been teaching at $[\mathrm{X}]$ ?

3. Have you taught at any other higher education institutions? Do you currently still teach at those institutions?

4. How does $[\mathrm{X}]$ compare to those other institutions in physical size, space, capacity, student population, type of institution-private, public, co-ed, number of undergraduate, graduate, and doctoral programs, etc.?

5. Has [X]'s mission had any influence on why you chose to teach at [X], or how you teach in the classroom?

6. What is your career background?

7. What is your discipline (specialty)?

8. Why did you choose a career in teaching in higher education?

9. How do you define job satisfaction?

10. How would you describe your teaching style? Classroom set-up?

11. Do you teach face-to-face, online, hybrid, undergraduate or graduate courses?

12. Do you teach summer sessions? Have you been offered to teach summer sessions?

13. How many students do you have per class on average?

14. How would you describe the $[\mathrm{X}]$ student?

15. How often are you on campus? For how long?

16. How much time do you spend grading and planning?

17. Are you involved in any other institutional development at [X] (clubs, offices, job roles)?

18. What professional organizations are you involved with?

19. How do you define contingent faculty?

20. What resources does you identify as most important in aiding in your job role and positive job satisfaction levels?

21. In what specific ways does your institution invest in their part-time faculty (i.e. pay, benefits, professional development programs, departmental inclusion (meetings, events), other resources available)?

22. Do you go to conferences for your job role? Why or why not? Has [X] funded those conferences?

23. Are there any individual ways $[\mathrm{X}]$ has individually supported or not supported you?

24. How has $[\mathrm{X}]$ helped you carry out their connected learning mission in the classroom and beyond?

25. What role do you play in your student's classroom experience? Their learning experience?

26. In your experience, what is rewarding about your job? The least rewarding? The most rewarding?

27. Do you have contact with other full-time faculty and administrators? For what purpose?

28. What are your interpersonal relationships like at $[\mathrm{X}]$ with other members of the institutional community (students, faculty, staff, etc.)?

29. Where do you see the future going for contingent faculty?

30. What are the differences you perceive, if any, between full-time and contingent faculty?

31. What is the culture of your institution surrounding contingent faculty?

32. How much does the institution rely on contingent faculty?

33. What is the rehiring process like?

34. Do you see yourself as replaceable? If so, why? 
35. Do you have a choice of what days/time and courses you teach?

36. How reliable do you feel your job is as a contingent faculty member? Do you see yourself as replaceable? If so, why?

37. Any thoughts about unionizing? 